\title{
Comparison of enzyme immunoassays and cell culture for detecting Chlamydia trachomatis
}

\author{
K C MOHANTY,* J J O’NEILL, $†$ AND M H HAMBLING $\dagger$ \\ From the *Department of Genitourinary Medicine, St Luke's Hospital, Bradford, and the $†$ Public Health \\ Laboratory Service, Leeds
}

SUMMARY Endourethral or endocervical swabs were taken from 403 patients to detect Chlamydia trachomatis by four different methods including standard tissue culture. Two immunoenzyme assays, Chlamydiazyme and IDEIA, were found to be satisfactory and could be valuable for large and busy sexually transmitted disease (STD) clinics.

\section{Introduction}

Chlamydia trachomatis is an important sexually transmitted organism. The diagnosis of infection with Ctrachomatis no longer depends on cell culture methods. After our report on a direct immunofluorescent technique, ${ }^{1}$ we experienced practical difficulties in performing and reporting these tests on as many as 50 specimens a day. In view of this workload we have tested the recently developed immunoassay techniques for detecting $C$ trachomatis and compared the results with those obtained by tissue culture methods.

\section{Patients, materials, and methods}

We studied 403 patients ( 150 men, 253 women; mean age 22.3 years) who attended the department of genitourinary medicine at St Luke's Hospital, Bradford. We used four different methods for detecting $C$ trachomatis; standard tissue culture as described in our previous report, ${ }^{1}$ solid phase $C$ trachomatis enzyme immunoassay (CT-EIA) (Abbott Diagnostics, Basingstoke, Hampshire, England), solid phase Chlamydiazyme (Abbott), and an amplified enzyme linked immunosorbent assay (ELISA) named IDEIA (Boots Celltech, Slough, Berkshire, England). We collected duplicate swabs to compare two methods at any one time. All the tests were carried out according to the manufacturers' instructions, and the tissue culture technique was as described previously. ${ }^{1}$

Address for reprints: Dr K C Mohanty, Department of Genitourinary Medicine, St Luke's Hospital, Bradford, West Yorkshire BD5 0NA

Accepted for publication 19 September 1985

\section{Results}

We assigned each of the 403 patients to one of three groups. Group 1 contained 102 patients whose specimens were studied by CT-EIA and tissue culture. Table I shows that $25(24.5 \%)$ gave positive results by both methods. CT-EIA alone gave positive results in seven cases $(6.9 \%)$ whereas culture alone gave positive results in four cases (3.9\%). The sensitivity of CT-EIA compared with tissue culture was found to be only $86.2 \%$ and the specificity was $90 \cdot 4 \%$. Group 2 (table II) consisted of 159 patients whose specimens were tested by CT-EIA and IDEIA. In $20(12.6 \%)$ both methods gave positive results. In two $(1.3 \%)$ patients the CT-EIA alone gave positive results, whereas in five (3.1\%) IDEIA alone gave positive results. Group 3 consisted of 142 patients whose specimens were examined by CT-EIA and the Chlamydiazyme test. Table III shows that 26 specimens $(18.3 \%)$ were positive by both methods, whereas three $(2 \cdot 1 \%)$ specimens were positive by CT-EIA and negative by Chlamydiazyme. In contrast, 13 specimens $(9 \cdot 2 \%)$ gave positive results by Chlamydiazyme and negative by CT-EIA.

\section{Discussion}

Tissue culture methods do not identify $100 \%$ of chlamydial infections and are associated with problems of contamination, insensitivity, and toxicity. In addition, transportation and storage must be under optimum conditions, and the presence of specific antibodies in cervical secretion may render the detection of $C$ trachomatis more difficult. ${ }^{2}$

The ELISA eliminates most of these problems. The 
TABLE I Comparison of CT-EIA and tissue culture for detecting Chlamydia trachomatis in 102 patients (group 1)

\begin{tabular}{|c|c|c|c|c|c|}
\hline \multirow[b]{2}{*}{ Patients } & \multirow[b]{2}{*}{$\begin{array}{l}\text { Specimens } \\
\text { examined }\end{array}$} & \multicolumn{4}{|c|}{ No (\%) of specimens: } \\
\hline & & $\begin{array}{l}\text { CT-EIA positive } \\
\text { culture positive }\end{array}$ & $\begin{array}{l}\text { CT-EIA positive } \\
\text { culture negative }\end{array}$ & $\begin{array}{l}\text { CT-EIA negative } \\
\text { culture positive }\end{array}$ & $\begin{array}{l}C T-E I A \text { negative } \\
\text { culture negative }\end{array}$ \\
\hline $\begin{array}{l}\text { Men } \\
\text { Women }\end{array}$ & $\begin{array}{l}42 \\
60\end{array}$ & $\begin{array}{l}12(28 \cdot 6) \\
13(21 \cdot 7)\end{array}$ & $\begin{array}{l}2(4 \cdot 8) \\
5(8 \cdot 3)\end{array}$ & $\begin{array}{l}1(2 \cdot 4) \\
3(5 \cdot 0)\end{array}$ & $\begin{array}{l}27(64 \cdot 3) \\
39(65 \cdot 0)\end{array}$ \\
\hline Total & 102 & $25(24 \cdot 5)$ & $7(6 \cdot 9)$ & $4(3.9)$ & $66(64 \cdot 7)$ \\
\hline
\end{tabular}

CT-EIA $=C$ trachomatis enzyme immunoassay.

TABLE II Comparison of CT-EIA and IDEIA for detecting Chlamydia trachomatis in 159 patients (group 2)

\begin{tabular}{|c|c|c|c|c|c|}
\hline \multirow[b]{2}{*}{ Patients } & \multirow[b]{2}{*}{$\begin{array}{l}\text { Specimens } \\
\text { examined }\end{array}$} & \multicolumn{4}{|c|}{ No (\%) of specimens: } \\
\hline & & $\begin{array}{l}\text { CT-EIA positive } \\
\text { IDEIA positive }\end{array}$ & $\begin{array}{l}C T-E I A \text { positive } \\
I D E I A \text { negative }\end{array}$ & $\begin{array}{l}\text { CT-EIA negative } \\
\text { IDEIA positive }\end{array}$ & $\begin{array}{l}C T-E I A \text { negative } \\
\text { IDEIA negative }\end{array}$ \\
\hline $\begin{array}{l}\text { Men } \\
\text { Women }\end{array}$ & $\begin{array}{r}56 \\
103\end{array}$ & $\begin{array}{r}6(10.7) \\
14(13.6)\end{array}$ & $\begin{array}{l}2(3 \cdot 6) \\
0\end{array}$ & $\begin{array}{l}1(1 \cdot 8) \\
4(3 \cdot 9)\end{array}$ & $\begin{array}{l}47(83 \cdot 9) \\
85(82 \cdot 5)\end{array}$ \\
\hline Total & 159 & $20(12 \cdot 6)$ & $2(1 \cdot 3)$ & $5(3 \cdot 1)$ & $132(83.0)$ \\
\hline
\end{tabular}

CT-EIA = $C$ trachomatis enzyme immunoassay.

TABLE III Comparison of CT-EIA and Chlamydiazyme for detecting Chlamydia trachomatis in 142 patients (group 3)

\begin{tabular}{|c|c|c|c|c|c|}
\hline \multirow[b]{2}{*}{ Patients } & \multirow[b]{2}{*}{$\begin{array}{l}\text { Specimens } \\
\text { examined }\end{array}$} & \multicolumn{4}{|c|}{ No (\%) of specimens: } \\
\hline & & $\begin{array}{l}\text { CT-EIA positive } \\
\text { Chlamydiazyme } \\
\text { positive }\end{array}$ & $\begin{array}{l}\text { CT-EIA positive } \\
\text { Chlamydiazyme } \\
\text { negative }\end{array}$ & $\begin{array}{l}\text { CT-EIA negative } \\
\text { Chlamydiazyme } \\
\text { positive }\end{array}$ & $\begin{array}{l}\text { CT-EIA negative } \\
\text { Chlamydiazyme } \\
\text { negative }\end{array}$ \\
\hline $\begin{array}{l}\text { Men } \\
\text { Women }\end{array}$ & $\begin{array}{l}52 \\
90\end{array}$ & $\begin{array}{l}10(19 \cdot 2) \\
16(17 \cdot 8)\end{array}$ & $\begin{array}{l}1(1 \cdot 9) \\
2(2 \cdot 2)\end{array}$ & $\begin{array}{l}4(7 \cdot 7) \\
9(10 \cdot 0)\end{array}$ & $\begin{array}{l}37(71 \cdot 2) \\
63(70 \cdot 0)\end{array}$ \\
\hline Total & 142 & $26(18 \cdot 3)$ & $3(2 \cdot 1)$ & $13(9 \cdot 2)$ & $100(70 \cdot 4)$ \\
\hline
\end{tabular}

CT-EIA $=C$ trachomatis enzyme immunoassay.

CT-EIA test was found to be $86 \cdot 2 \%$ sensitive when compared with tissue culture. In the seven specimens that were CT-EIA positive and culture negative, the results may be attributed to false positive results by the immunoassay test or merely loss of viability of the chlamydial organism. Four specimens were positive by culture but negative by CT-EIA, which suggests that the EIA is less sensitive than culture.

The results of the comparison between the CT-EIA and the IDEIA, which is described as an amplified enzyme immunoassay, are shown in table II. These indicate that the IDEIA would detect more infections than the CT-EIA.

The results of the comparison between CT-EIA and the Chlamydiazyme test, both produced by Abbott Diagnostic Laboratories, are shown in table III and support the manufacturers' claims that the Chlamydiazyme is more sensitive than the original CT-EIA.

From the practical and technical point of view there are no great advantages or disadvantages between the Chlamydiazyme test and the IDEIA and the choice may well depend on the equipment available in the laboratory. Having to boil the specimens during the IDEIA is possibly a disadvantage, but it can be argued that this adds a safety factor to the procedure.

In conclusion, our investigations have shown that both the Chlamydiazyme test and IDEIA are satisfactory for carrying out large numbers of tests to identify C trachomatis. These commercial kits may prove valuable for busy clinics, not only in obtaining rapid diagnoses, but also in eliminating some of the problems associated with storage, transportation, and contamination.

We thank the staff of the genitourinary clinic for their part in this investigation and Ms P M Lodge for typing the manuscript.

\section{References}

1. Foulkes SJ, Deighton R, Feeney ARB, Mohanty KC, Freeman CWJ. Comparison of direct immunofluorescence and cell culture for detecting Chlamydia trachomatis. Genitourin Med 1985;61:255-7.

2. Mårdh P-A, Lind I, Svensson L, Weström L, Møller BR. Antibodies to Chlamydia trachomatis, Mycoplasma hominis, and Neisseria gonorrhoeae in sera from patients with acute salpingitis. British Journal of Venereal Diseases 1981;57:125-9. 